CROSS-BORDER INSOLVENCY LAW IN EUROPE: PRESENT STATUS AND FUTURE PROSPECTS

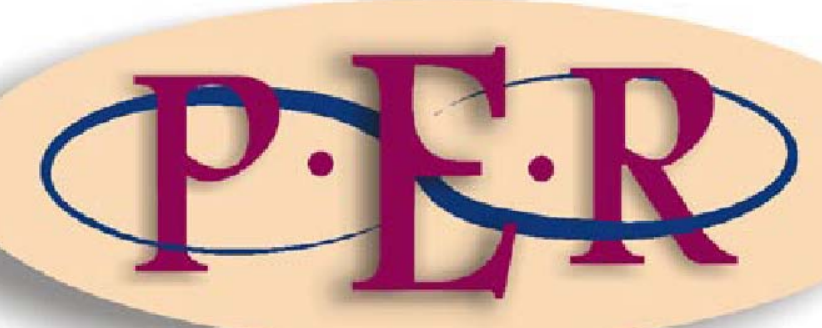

2008 VOLUME 11 NO 1 


\section{CROSS-BORDER INSOLVENCY LAW IN EUROPE: PRESENT STATUS AND FUTURE PROSPECTS}

\section{B Wessels*}

\section{$1 \quad$ Introduction}

In May 2007 Europe celebrated the first lustrum of the EU Insolvency Regulation (number 1346/2000). The regulation is not the only legal measure of such a young age which has influenced cross-border insolvency law in Europe. The $21^{\text {st }}$ century has started with several legislative measures of importance for insolvencies with a cross-border effect in the European Community. In 2000 birth was given to said EU Insolvency Regulation (InsReg), which entered into force 31 May 2002. For several financial institutions, falling outside the regulation's scope, 2001 produced Directive 2001/17 and Directive 2001/24 on the reorganisation and winding-up of insurance undertakings and of credit institutions. Where a regulation is a European Community law measure binding fully the EU Member States, both directives have to go through a legislative implementation process in each individual EEA (European Economic Area) Member State. The implementation date for Directive 2001/24 was 20 April 2003 and for Directive 2001/24 it was 5 May 2004. As far as can be assessed, all EU countries have implemented these directives. ${ }^{1}$

* Bob Wessels, Professor International Insolvency Law, Leiden University, the Netherlands; Adjunct Professor International and Comparative Insolvency Law, St. John's University, School of Law, New York, USA.

1 For commentaries on both directives and for Member State implementation reviews, see Moss and Wessels (eds) EU Banking and Insurance Insolvency. It should be noted that Denmark is not bound by the Insolvency Regulation (InsReg). 
In this article a description is given as to where Europe stands (as per August 2006). On the European level the regulation has introduced a model based on well known theories of private international law for dealing with cross-border insolvencies (see paragraphs 2 and 3). The EU Insolvency Regulation provides for a national court to exercise international jurisdiction to open insolvency proceedings. The basis for international jurisdiction is the debtor's 'centre of main interests' or COMI. It is discussed in paragraph 4, with a treatment of the two cases the European Court of Justice (of 17 January 2006 and 2 May 2006) has dealt with until now (paragraphs 5 and 6). The EU Insolvency Regulation carries its own legal concept (see paragraph 7). The regulation should be seen in its procedural context, as it fills the gap, which had been left open by the introduction of (what then was) the 1968 Brussels Convention dealing with the international jurisdiction and recognition of judgments in civil and commercial matters. In the context of legal proceedings the latter (now known as the Brussels Regulation 2000) forms the general rule, the regulation (for insolvency judgments) itself forms the special rule. As 'financial institutions' are not covered by the Insolvency Regulation, the latter serves in its turn as a general rule with regard to credit institutions and insurance undertakings, for which entities said Directives 2001/17 and 2001/24 have been issued (see paragraph 8). After having taken stock a list will be drawn of some suggestions for improvement of the system of cross-border insolvency in Europe.

\section{Coordinated universality as basic model}

The activities of undertakings have more and more cross-border effects and are therefore increasingly being regulated by Community law. While the insolvency of such undertakings also affects the proper functioning of the internal market, there is a need for a 
Community act requiring coordination of the measures to be taken regarding an insolvent debtor's assets. ${ }^{2}$

So, what is the chosen approach to reach a proper functioning of the internal EU market when confronted with cross-border insolvency cases? These cases include instances where the insolvent debtor has assets in more than one Member State or where some of the creditors of the debtor are not from the state where the insolvency proceeding is taking place. These instances cause a great number of sometimes rather complex legal questions, such as the international jurisdiction of the court which is authorised to open insolvency proceedings, the law applicable to the insolvency proceedings and on the substantial and procedural effects of these proceedings, for example, on the legal position of creditors from abroad and their rights to set-off or the termination of employment contracts, the issue of recognition of proceedings which have been opened abroad, the powers of a liquidator or administrator who has been appointed abroad, etcetera.

From way back, the issues to be solved concerning cross-border insolvencies are being approached from two points of departure: 'universality' and 'territoriality'. In the universality model insolvency proceedings are seen as a unique proceeding reflecting the unity of the estate of the debtor. The proceeding should contain all of the debtor's assets, wherever in the world these assets are located. In this approach the whole estate will be administered and reorganised or liquidated based on the rules of the law of the country where the debtor has his domicile (or registered office or a similar reference location) and in which country the proceedings have been opened. The applicable law for the proceedings and its legal and procedural consequences is the law of the state in which the insolvency measure has been issued. This 
law often is referred to as lex concursus, lex forum concursus (or: forum law), being the law (lex) of the country where a court (forum) opened insolvency proceeding (dealing with concurring claims of creditors: concursus) and which court is (or has been) charged with hearing, conduct and closure of the proceedings. The liquidator (or administrator) in this approach is charged with the liquidation (or reorganisation) of the debtor's assets all over the world of which the debtor himself (partly) has been divested respectively he is charged with the supervision of the administration of his affairs. The lex concursus determines all consequences of these proceedings, for example, with regard to current contracts, the powers of an administrator and the bases and system of distributing dividends to creditors. The territoriality model on the other hand takes as a basic idea that the respective insolvency measure only will have legal effects within the jurisdiction of the state within the territory of which a court has opened the insolvency proceedings. The legal effects of these proceedings therefore will abruptly stop at this state's borders. The limitations these proceedings will bring to a debtor's legal authority to administer his assets are not applicable abroad. Assets in other countries will not be affected by these proceedings and the administrator who is appointed will not have any powers abroad.

These points of departure form both ends on a scale and are discussed extensively and sometimes sharply in literature. ${ }^{3}$ In practice, most countries modify or limit the sharp edges of these theories and have introduced modified or mixed models, mostly referred to as 'modified', 'limited' or 'mitigated'

3 See Wessels International Insolvency Law par 10009ff. See also eg, Kolmann Kooperationsmodelle for an expansion on "Models of cooperation in international insolvency law: is a new orientation to be recommended for German international insolvency law?"; Westbrook 2004 Texas Law Review 795; Pottow 2005 Virg J Int'l L http://ssrn.com/abstract=646962 27 Feb; Janger 2007 Brooklyn Journal of International Law (forthcoming) and Rasmussen 2007 Vanderbilt Law and Economics http://ssrn.com/ 18 Feb. 
universality (or: universalism), as most of them in their core have a universal element. The EU Insolvency Regulation is based on a mixed model, referred to in this article as 'coordinated' universality. ${ }^{4}$

\section{The EU Insolvency Regulation}

On 31 May 2002 Regulation (EC) Number 1346/2000 of 29 May 2000 on insolvency proceedings entered into force. The regulation applied entirely and directly to the ten Member States, which joined the EU as of 1 May 2004, and to Bulgaria and Romania, when these countries joined the EU as of 1 January 2007..$^{5}$ As indicated, a regulation is a European Community law measure, which is binding and directly applicable in Member States. ${ }^{6}$ The regulation does not apply to Denmark, as it opted out in accordance with the Treaty of Amsterdam. In the light of the introduction above it should be mentioned that the regulation acknowledges the fact that as a result of widely differing substantive laws in the Member States "it is not practical to introduce insolvency proceedings with universal scope in the entire Community". ${ }^{7}$ The differences mainly lie in the widely differing laws on security interests to be found in the Community and the very different preferential rights enjoyed by some creditors in the insolvency proceedings. The goals of the regulation, with

4 Coordination is to be found especially in the mutual duties for liquidators in insolvency proceedings, pending in different EU Member States, to communicate information and to cooperate, see art 31 InsReg. See also Wessels 2005 International Corporate Rescue $291 \mathrm{ff}$.

5 A consolidated version of the text of the Insolvency Regulation can be found at Wessels http://www.bobwessels.nl 18 Feb (Blog 2007-01-doc16). The Annexes to the Insolvency Regulation have been amended several times, the latest version being of June 2007; see Wessels http://www.bobwessels.nl 18 Feb (Blog 2007-06-doc3).

6 A regulation therefore does not allow 'implementation' as it binds Member States directly. In several countries though, national legislation is (or should be) adopted in order to make the Insolvency Regulation compatible with national procedural law, see for Germany, France and the Netherlands: Wessels Realisation 229.

7 Recital 11. 
47 articles, are to enable cross-border insolvency proceedings to operate efficiently and effectively, to provide for co-ordination of the measures to be taken with regard to the debtor's assets and to avoid forum shopping. The regulation, therefore, provides rules for the international jurisdiction of courts in a Member State for the opening of insolvency proceedings, the (automatic) recognition of these proceedings in other Member States and the powers of the 'liquidator' in the other Member States. The regulation also deals with important provisions for choice of law (or: private international law). These contain special rules on applicable law in the case of particularly significant rights and legal relationships (for example, rights in rem and contracts of employment). On the other hand, national proceedings covering only assets situated in another Member State than the state of opening are allowed alongside main insolvency proceedings, which have in principle a universal scope. The law of the state of opening spreads its effects all over Europe.

The following provides a quick scan of the contents of the Insolvency Regulation.

The general provisions establish the area of application of the regulation. It is confined to "proceedings which entail the partial or total divestment of a debtor and the appointment of a liquidator". ${ }^{8}$ Annex A contains all insolvency proceedings of the Member States; annex $C$ mentions all names of the office holders (in the regulation referred to as 'liquidators'). As far as the jurisdiction of a court is concerned the regulation is based on the general principle that -

the courts of the Member State within the territory of which the centre of the debtor's main interests is situated shall have jurisdiction to open insolvency proceedings. ${ }^{9}$

8 See art 1(1) InsReg.

9 See art 3(1). 
For a company or legal person, the presumption is that the centre of the debtor's main interests is the place of its registered office, but this presumption may be rebutted (article 3(1) last line). The debate whether indeed a debtor (natural persons, legal persons, except financial institutions) has its centre of main interest (in international jargon: COMI) in a certain jurisdiction has been heard by many courts in Europe. The opened insolvency proceeding is called main proceedings. Its most important consequence is that the law applicable to insolvency proceedings under the regulation is that "of the Member State within the territory of which such proceedings are opened", ${ }^{10}$ thus: lex concursus, and that the opened proceeding shall be recognised automatically in all other Member States (article 16). In addition, the court of another Member State than the State of opening main proceedings shall only have jurisdiction, if "the debtor possesses an establishment within the territory of that other Member State" (article 3(2)). ${ }^{11}$ The effects of the latter proceedings - referred to as secondary proceedings - are however restricted to the assets of the debtor situated in the territory of the other Member State (article 3(2) last line) and this proceeding may only be a winding-up proceeding. In the framework of main proceedings and secondary proceedings one notes the combination of universality and territoriality, as referred to above.

The 'centre of main interests' (COMI) -

should correspond to the place where the debtor conducts the administration of his interests on a regular basis and is therefore ascertainable by third parties. ${ }^{12}$

10 See art 4(1).

11 Art 2(h) provides that for the purposes of the EU Insolvency Regulation an 'establishment' shall mean "any place of operations where the debtor carries out a non-transitory economic activity with human means and goods". As recital 13 provides. 
In some 70 percent of all court cases from the mid of 2002 until now the determination of COMI is the principle point of legal conflict ${ }^{13}$, with highly debated cases like Daisytek (involving sixteen subsidiaries in UK, Germany and France) ${ }^{14}$ and Parmalat (involving Italy, Ireland, the Netherlands and Luxembourg). The outcome of the question, "where is the centre of main interest?" in these decisions is based on many facts and circumstances, amongst (very many) others the fact that:

(i) The day to day administration is conducted in the forum State (Ireland), ${ }^{15}$

(ii) The directors possessed the forum's nationality (Italy), ${ }^{16}$

(iii) The (Delaware incorporated) company had presented itself to its most substantial creditor as having its principle executive offices in the forum State (England), ${ }^{17}$

(iv) The debtor (natural person) has maintained, with regard to the substantial interests in a large number of companies established in the forum State, to administer these commercial interest in the forum State (the Netherlands), ${ }^{18}$

(v) The director (of an Irish incorporated company, being a wholly owned subsidiary of a UK company) was based in the UK and was solely responsible for the companies business, ${ }^{19}$

Sources or extracts of some 200 court cases can be found at http://ww.eir-database.com.

14 These European subsidiaries were left out of a filing of a Chapter 11 case in the USA (Dallas, Texas) for the overall holding of Daisytek International, Inc.

15 Court of Dublin 23 March 2004 in Re Eurofood IFSC Limited (Irish company, part of the Parmalat group).

16 Court of Parma 19 February 2004 in Re Eurofood IFSC Limited.

17 Court of Leeds (Ch D) 20 May 2004 in Re Ci4net.com Inc and Re DBP Holdings Limited.

18 Netherlands Supreme Court 9 January 2004, JOR 2004/87, with my commentary.

19 High Court London (Ch D) 2 July 2004 in Re Aim Underwriting Agencies (Ireland) Ltd. 
(vi) Some remaining contractual works (conducted by a company incorporated in Finland) were still in progress in the forum State (Sweden), ${ }^{20}$

(vii) The group's parent company (of an Austrian company with its seat in Innsbruck) is located in the forum State (Germany), ${ }^{21}$

(viii) The company (registered in the UK with a postal address in Spain) is a partner in a Swedish limited partnership (kommanditbolag) (Sweden), ${ }^{22}$

(ix) The codes to the computer programmes of the debtor company (registered in the UK, postal address in the UK, premises in Sweden) are stored in the forum State (Sweden), ${ }^{23}$

(x) The strategy committee and other board meetings are held in the forum state, ${ }^{24}$ and

(xi) The company's bank accounts are located in the forum state. ${ }^{25}$

The regulation provides for several exceptions to the application of the lex concursus, see articles 5-15 InsReg. These exceptions include third parties' rights in rem and reservation of title (articles 5 and 7) and set-off rights (article 6). These rights (under certain conditions) are however not affected by the legal consequences (lex concursus) of the opening of main proceedings. In other instances exclusion is made in that another choice of law (instead of the lex concursus) has been made. Important examples are contracts relating to immovable property (article 8: effects of insolvency proceedings shall be governed by the law of the Member State within the territory of which the immovable property is situated) and contracts of employment (article 10:

Svea Court of Appeal 30 May 2003 (No Ö 4105-03; on file with author).

Court of Munich 4 May 2004 in Re Hettlage KgaA.

Court of Appeal Skåne and Blekinge 3 February 2005 (No Ö 21-05; on file with author).

Court of Stockholm 21 January 2005 (K 17664-04).

In Re Sendo Ltd [2005] EWHC 1604 (Ch).

In Re Collins \& Aikman Europe SA [2005] EWCH 1754 (Ch). 
governed by the law of the Member State applicable to the contract of employment).

Insolvency proceedings opened in the opening state where the debtor has his centre of main interests will be (automatically, article 16) recognised in all the other Member States. Nevertheless, such recognition does not prohibit the opening of secondary proceedings in a state where the debtor owns an 'establishment', article 16(2). The regulation describes furthermore, amongst others, the powers of a liquidator, the publication of the opening judgement in another Member State or in public registers. Any creditor has the right to lodge claims in writing, if his residence is located in a Member State other than the state of the opening of proceedings. This provision is meant also for the tax authorities and social security authorities (article 39). ${ }^{26}$ The regulation further provides for a duty to inform known creditors in the other Member State and the language to be used in the specific notice.

In general, the EU Insolvency Regulation only applies to intra-Community relations; in cross-border insolvency cases relating to non-EU states the rules of general private international law or specific legislation of a country (domestic or contained in a treaty) in this field apply.

26 The High Court of Ireland of 8 March 2005 in Re Cedarlease Ltd considers that the Insolvency Regulation does not expressly provide that a creditor located in another Member State (that is, the Commissioners of Customs \& Excise for the UK) shall have the right to initiate insolvency proceedings, but in the court's view, it would defeat the purpose of the Insolvency Regulation if that were not the case. 


\section{$4 \quad$ How to determine COMI?}

It may follow from the above that courts determine on COMI following the interpretation of a super abundance of facts. In general, it would be submitted, in these court cases one sees the confrontation of two concepts. The first one is a 'Contact with Creditors' (sometimes: 'business activity') approach: through the eyes of creditors a debtor's COMI has to be determined. After all, recital 13 provides that COMI should correspond to the place where the debtor conducts the administration of his interests on a regular basis "and is therefore ascertainable by third parties" (italics added). A simple example is the case decided by the District Court Dordrecht 23 November 2005. ${ }^{27}$ A creditor has filed for insolvency proceedings concerning a debtor on 13 September 2005. The request is dealt with by the Court on 23 November 2005. The debtor, though appropriately summoned, did not appear. The court based its international jurisdiction on article 3(1) in the light of recital 13. It turns out from the public municipal records that the debtor prior to the date of filing, namely 4 May 2005, has left for Belgium. Therefore, according to the court, Belgium is the debtor's COMI unless it is proven that his COMI is in the Netherlands. It is not enough that debtor's small business registration in the Trade Register was crossed out on 11 October 2005, ex officio by the keeper of the register (a date following the date of filing). It has not been proven that the debtor still continues to display activities and the fact that he still has several debts towards the filing creditor is insufficient to assume that his COMI is in the Netherlands; therefore the Dutch courts do not have jurisdiction to open main insolvency proceedings, thus the Dordrecht court.

The other view is the 'Mind of Management' approach (sometimes called: 'Head Quarters', 'head office functions' or 'parental control' approach). An example is 
the following case of High Court of Justice (Chancery Division Companies Court) 15 July 2005 (Collins \& Aikman Europe SA). ${ }^{28}$ In the UK an application for administration orders is made concerning 24 companies in the Collins \& Aikman Corporation Group, of which one is incorporated in Luxembourg, six in England, one in Spain, one in Austria, four in Germany, two in Sweden, three in Italy, one in Belgium, four in The Netherlands and one in the Czech Republic. The Collins \& Aikman Group has its headquarters in Michigan, USA. It is a leading global supplier of automotive component systems and modules to the world's largest vehicle manufacturers, including Daimler, Ford, General Motors, Honda, Nissan, Porsche, Renault, Toyota and Volkswagen. It has a combined workforce of approximately 23,000 employees and a network of more than 100 technical centres, sales offices and manufacturing sites in 17 countries throughout the world. In Europe it operates 24 facilities in 10 countries with 4,500 staff. Its largest customers are Daimler, Daimler Chrysler, General Motors and Ford, which accounts for approximately $60 \%$ of the business of the European operations. The group has in recent years grown considerably, primarily from acquisitions, but it has got into financial difficulties by virtue of its liquidity position and as a result the US operations of the group went into chapter 11 proceedings in the United States in May 2005. The High Court pays attention to recital 13 and several English court decisions regarding the question of the location of the centre of main interests. ${ }^{29}$ The norm of recital 13 ("the place where the debtor conducts the administration of his interests on a regular basis and is ascertainable by third parties") has to be applied and the court finds its guidance in English literature ${ }^{30}$ according to which in order to rebut the presumption that the relevant place is the place of incorporation, it will

28 High Court of Justice (Chancery Division Companies Court) 15 July 2005, [2005] EWHC 1754 (Ch) (Collins \& Aikman Europe SA), supra n 25.

29 Including BRAC Rent-A-Car International Inc [2003] 1 WLR 40 1421, and Re Daisytek-ISA Ltd [2004] BPIR 30.

30 Collins et al (eds) Conflict of Laws 158 Supplement S30. 
be necessary to show that 'the head office functions' are carried out in a member state other than the state in which the registered office is situated. The court assesses the evidence from the companies and considers that the main administrative functions relating to the European operations have since 17 May 2005 been carried out from England: cash co-ordination, pooling bank accounts for the European operations, coordination of human resources, operation of the IT system. Furthermore, the court considers that the majority of the sales functions in relation to the European operations are dealt with from England, in particular, the principal customer in Europe, Ford, and accounting for approximately $60 \%$ of revenue. All sales to Ford are handled by the Ford Business Unit in England. The court, finally, is satisfied on the evidence that the COMI of each of the non-English companies were not related to the location of their respective registered offices.

From the questions this judgment raises mention now follows only on the nature of the approach. With due respect it is submitted that nor from the history, nor from the recitals or the text of the regulation, it follows that the carrying out of head quarter functions has weight and meaning in the context of deciding the issue of international jurisdiction of a court. It only functions as an explanation for said presumption. Another question is whether this should be the most desirable approach, but to follow it, the text of the regulation should be changed or the European Court of Justice (ECJ) may provide such an interpretation. It is doubted that this will be the case. ${ }^{31}$

31 See Wessels International Insolvency Law. See also Wessels Open Insolvency Proceedings 155; Huber Europäischen Insolvenzverordnung 397; and Bufford 2006 Columbia Journal of European Law 429. 


\section{European Court of Justice 2 May 2006 (Eurofood)}

On 2 May 2006 the European Court of Justice published its long awaited judgment, which is also important for the interpretation of COMI. Eurofood IFSC Ltd is registered in Ireland in 1997 as a 'company limited by shares' with its registered office in the International Financial Services Centre in Dublin. It is a wholly owned subsidiary of Parmalat SpA, a company incorporated in Italy, whose principal objective was the provision of financing facilities for companies in the whole Parmalat group. On 24 December 2003, in accordance with Decree-Law No 347 of 23 December 2003 (Amministrazione straordaninaria delle grandi impresi in stato di insolvenza or extraordinary administration for large insolvent undertakings), ${ }^{32}$ Parmalat SpA was admitted to extraordinary administration proceedings by the Italian Ministry of Production Activities, who appointed $\mathrm{Mr}$ Bondi as the extraordinary administrator of Parmalat. On 27 January 2004, the Bank of America applied to the High Court (Ireland) for compulsory winding-up proceedings to be commenced against Eurofood and for the nomination of a provisional liquidator. That application was based on the contention that Eurofood was insolvent. The Irish High Court appointed on the same day $\mathrm{Mr}$ Farrell as the provisional liquidator, with powers to take possession of all the company's assets, manage its affairs, open a bank account in its name, and instruct lawyers on its behalf. Two weeks later, on 9 February 2004, the Italian Minister for Production Activities admitted Eurofood to the extraordinary administration procedure and appointed Mr Bondi as the extraordinary administrator. This was followed a day later by an application filed before the District Court in Parma (Italy) for a declaration that Eurofood was insolvent. The hearing was fixed for 17 February 2004, Mr Farrell being informed of that date only on 13 February. On 20 February 2004, the District 
Court in Parma, taking the view that Eurofood's COMI was in Italy, held that it had international jurisdiction in the meaning of article 3(1) InsReg to determine whether Eurofood was in a state of insolvency.

Back to Ireland: by 23 March 2004 the High Court decided that, according to Irish law, the insolvency proceedings in respect of Eurofood had been opened in Ireland on the date on which the application was submitted by the Bank of America, namely 27 January 2004. Taking the view that the COMI of Eurofood was in Ireland, it held that the proceedings opened in Ireland were the main proceedings. It also held that the circumstances in which the proceedings were conducted before the District Court in Parma were such as to justify, pursuant to article 26 InsReg (public policy exception), the refusal of the Irish courts to recognise the decision of that court. Finding that Eurofood was insolvent, the High Court made an order for winding-up and appointed Mr Farrell as the liquidator. Mr Bondi appeals against that judgment and the Irish Supreme Court considered it necessary, before ruling on the dispute before it, to stay the proceedings and to refer the question regarding COMI to the Court of Justice for a preliminary ruling.

On this topic the European Court of Justice 2 May 2006 (Case C-341/04) rules as follows:

Where a debtor is a subsidiary company whose registered office and that of its parent company are situated in two different Member States, the presumption laid down in the second sentence of Article 3(1) of Council Regulation (EC) No 1346/2000 of 29 May 2000 on insolvency proceedings, whereby the centre of main interests of that subsidiary is situated in the Member State where its registered office is situated, can be rebutted only if factors which are both objective and ascertainable by third parties enable it to be established that an actual situation exists which is different from that which location at that registered office is deemed to reflect. That could be so in particular in the case of a company not carrying out any business in the territory of the Member State in which its registered office is situated. By contrast, where a company carries on its business in the territory of the Member State where its registered office is situated, 
the mere fact that its economic choices are or can be controlled by a parent company in another Member State is not enough to rebut the presumption laid down by that Regulation.

The other important decision is that the main insolvency proceedings opened by a court of a Member State must be recognised by the courts of the other Member States, without the latter being able to review the jurisdiction of the court of the opening state. Another judgment of the ECJ is that a decision to open insolvency proceedings for the purposes of article 16's rules of automatic recognition is a decision handed down by a court of a Member State to which application for such a decision has been made, based on the debtor's insolvency and seeking the opening of proceedings referred to in annex $A$ to the regulation, where that decision involves the divestment of the debtor and the appointment of a liquidator referred to in annex $C$ to the regulation. Such divestment implies that the debtor loses the powers of management that he has over his assets. This all means that the judgment based on the application on 27 January 2004 before the High Court (Ireland) must be recognised.

As a follower of the 'contact with creditors' approach personal concurrence is with the decision with regard to COMI. For a company or legal person, the presumption is that the centre of the debtor's main interests is the place of its registered office, but this presumption may be rebutted. The presumption should be taken serious. It only can be rebutted "if factors which are both objective and ascertainable by third parties" enable it to be established that reality differs from the legal form (the formal location at that registered office). The ECJ provides two examples: (i) when a company is not carrying out any business in the territory of the Member State in which its registered office is situated, and (ii) where a company carries on its business in the territory of the Member State where its registered office is situated. In the first example (PO Box companies; sham companies) the presumption may easily be rebutted. In the second example COMI could be in the other Member State, but "the mere fact that its economic choices are or can be controlled by a parent company in 
another Member State" is not enough to rebut the presumption. Internal 'invisible' (potential) control by the parent will be not or hardly ascertainable. Rebutting the presumption based on these facts does not work. That is only possible if factors which are both objective and ascertainable by third parties would lead to that consequence.

\section{European Court of Justice 17 January 2006 (Susanne Staubitz- Schreiber)}

In the beginning of 2006 the first full case concerning the application of the Insolvency Regulation has been given by the European Court of Justice on 17 January 2006 (Case C-01/04). The decision also concerns COMI, but this time for a natural person. The applicant for opening insolvency proceedings is Susanne Staubitz-Schreiber, a resident in Germany where she operated a telecommunications equipment and accessories business as a sole trader. She ceased to operate that business in 2001 and requested, on 6 December 2001, the opening of main insolvency proceedings regarding her assets before the Court in Wuppertal. On 1 April 2002, she moved to Spain in order to live and work there. By judgment of 10 April 2002, the Wuppertal Court refused to open the insolvency proceedings applied for on the ground that there were no assets. The appeal brought by the applicant in the main proceedings against that order was dismissed on the ground that the German courts did not have jurisdiction to open insolvency proceedings in accordance with article 3(1) InsReg, since the COMI of the applicant in the main proceedings was situated in Spain. Susanne brought an appeal before the Bundesgerichtshof (BGH German Supreme Court) in order to have the latter order set aside and the case referred back to the court in Wuppertal. She submits that the question of jurisdiction should be examined in the light of the situation at the time when the request to open insolvency proceedings was lodged, or, in this case, by taking account of 
her domicile in Germany in December 2001. The German Supreme Court refers the following question to the ECJ for a preliminary ruling:

Does the court of the Member State which receives a request for the opening of insolvency proceedings still have jurisdiction to open insolvency proceedings if the debtor moves the centre of his or her main interests to the territory of another Member State after filing the request but before the proceedings are opened, or does the court of that other Member State acquire jurisdiction? ${ }^{33}$

Where is Susanne's COMI? It follows that, in the case in the main proceedings, the national court must determine whether it has jurisdiction in the light of article 3(1). The ECJ indicates that this provision does not specify whether the court originally seized retains jurisdiction if the debtor moves the centre of his or her main interests after submitting the request to open proceedings but before the judgment is delivered. The ECJ considers that a transfer of jurisdiction from the court originally seized to a court of another Member State on that basis would be contrary to the objectives pursued by the regulation. The ECJ submits that the preambles to the regulation express the intention to avoid incentives for the parties to transfer assets or judicial proceedings from one Member State to another, seeking to obtain a more favourable legal position:

That objective would not be achieved if the debtor could move the centre of his main interests to another Member State between the time when the request to open insolvency proceedings was lodged and the time when the judgment opening the proceedings was delivered and thus determine the court having jurisdiction and the applicable law.

33 The ECJ first has to deal with the transitional provision of art 43 InsReg, laying down the principle governing the temporal conditions for application of that regulation. The court considers that art 43 must be interpreted as applying if no judgment opening insolvency proceedings has been delivered before the Regulation's entry into force on 31 May 2002, even if the request to open proceedings was lodged prior to that date. That was is in fact the case here, since the request by the applicant in the main proceedings was lodged on 6 December 2001 and no judgment opening insolvency proceedings was delivered before 31 May 2002. 
Transfer of jurisdiction would also be contrary to the objective of efficient and effective cross-border proceedings and retaining the jurisdiction of the first court seized ensures greater judicial certainty for creditors who have assessed the risks to be assumed in the event of the debtor's insolvency with regard to the place where the centre of his main interests was situated when they entered into a legal relationship with him. Concluding:

The answer to be given to the national court must therefore be that Article 3(1) of the Regulation must be interpreted as meaning that the court of the Member State within the territory of which the centre of the debtor's main interests is situated at the time when the debtor lodges the request to open insolvency proceedings retains jurisdiction to open those proceedings if the debtor moves the centre of his main interests to the territory of another Member State after lodging the request but before the proceedings are opened.

It is interesting to note that in the ECJ's approach to the aims and objectives of the Insolvency Regulation the recitals in the preamble are pivotal. Furthermore, emphasis is laid on the interests and the protection of creditors, which seems to function as a forerunner of the ECJ decision in the Eurofood case. ${ }^{34}$ On 9 February 2006 the German Supreme Court decided that the judgment of the Wuppertal Court of 10 April 2002 is overturned and the Supreme Court referred the matter for a new decision to the same court. ${ }^{35}$

\section{$7 \quad$ Coordination of proceedings}

As noted, a secondary proceeding only can have a winding-up character (article 27). The model of main proceedings in one Member State and 
concurring secondary proceedings (in one or more other Member States) having this nature, has been criticised. It is submitted however that this limitation flows from the clear desire "to achieve a system of international cooperation that is simple and easy to understand", see Virgós. ${ }^{36}$ At the same time, during the preparation of (what now is) the Insolvency Regulation the predominating thought was that -

the rules of mandatory coordination and the influence rights given to the main trustee would provide enough means to protect the rescue efforts in the main forum. This line of reasoning explains the rule adopted: secondary proceedings are possible, provided they are of the winding-up type, but they are subject to the ..... main-secondary scheme of coordination. ${ }^{37}$

It is mainly in the power of the liquidator in the main insolvency proceedings to exercise measures for coordination, for example, he may request opening of secondary proceedings in other Member States (article 29), participate in secondary proceedings (article 32(3)), request a stay of the process of liquidation of secondary proceedings (article 33(1)), request termination of this stay (article 33(2)), propose a rescue plan in the context of these secondary proceedings or he may disagree with finalising liquidation in secondary proceedings (article 34(2)). He shall furthermore lodge all claims in the secondary proceedings which have been lodged in the main proceedings (article 32(2)), he is duty bound to communicate information (article 31(1)) and to cooperate (article 31(2)). Both latter obligations are duties for liquidators in secondary proceedings too. The mutual duty between liquidators to communicate and to cooperate symbolises the bridging of the still existing deficit of uniform law. The performance of the obligations to communicate and 
to cooperate is necessary in order to voice, with regard to all claims, the principle of equal treatment of pari passu ranked creditors.

In a dozen or so separate provisions the Insolvency Regulation gives shape to the idea of 'unity of estate' (there is after all only one debtor), with regard to which he who has the most dominant role (the main liquidator) in principle directs the completion of the insolvency process, under the supervision of a national court. In this process the main liquidator has, with regard to any secondary proceedings, a set of controlling or coordinating (procedural and substantive) powers which he can exert. It is for this reason that for the model of international insolvency law in the system of the EU the description of 'coordinated universalism' is used.

\section{The procedural context}

The formal insolvency proceedings form the point of view of the Communities' approach to tackle certain problems in cross-border insolvencies, as the Insolvency Regulation is part of a more comprehensive framework with regard to cross-border effects of legal proceedings. The general rule here was already laid down in the 1968 Brussels Convention on Jurisdiction and the Enforcement of Judgments in Civil and Commercial Matters. Insolvency proceedings relating to the winding-up of insolvent companies or other legal persons, judicial arrangements, compositions and analogous proceedings are excluded from the scope of the 1968 Brussels Convention, which itself has been transformed into a Regulation too as of 1 March 2002. ${ }^{38}$ The EU Insolvency Regulation aims to fill this gap. Not all debtors, though, are covered by the Insolvency Regulation. Insolvency proceedings concerning insurance undertakings, credit institutions, 
investment undertakings, holding funds or securities for third parties and collective investment undertakings are excluded from the scope of the Insolvency Regulation, see article 1(2) InsReg.

The entities and undertakings which fall under the definitions given by the relevant community regulations and directives are excluded from the Insolvency Regulation since they are subject to special arrangements and, to some degree, national supervisory authorities have extremely wide-ranging powers of intervention, see recital 9 of the Insolvency Regulation. The special position of these financial organisations is based on the special role they play in a country's economy (banks typically hold highly liquid liabilities; insurance companies guarantee central interests of policy holders). The EU banking and insurance sector has adopted a single entity approach, which is subject to the supervision of the competent authorities of the state where authorisation valid throughout the community was granted ('single licence' with 'home country control'). In this approach in principle said financial institutions are wound up as one legal entity and therefore, for example, the assets of a bank in its home state jurisdiction are encompassed in the liquidation, which assets include the assets of branches in a host state jurisdiction. This strongly reflects a universality principle. For this reason the directives do not allow the opening of secondary proceedings, as these would hinder the goal of supervision. Both directives furthermore require an early exchange of information between supervising authorities and enable for coordination of reorganisation measures or winding-up proceedings for insurance undertakings and banks with branches in other Member States. Such provisions would seem odd in general insolvency cases and the prevention of financial failure. ${ }^{39}$ 


\section{2 - 2007: A positive balance, but improvements are required}

A generally felt assessment is that the EU Insolvency Regulation works quite well. The measurement should be taken by assessing the EU Insolvency Regulation's initial aims, centred around: (a) the proper functioning of the internal market (recital 2), (b) preventing the supply of incentives to seek more favourable legal positions (forum shopping, recital 4), (c) improvement of efficiency and effectiveness in cross-border insolvencies, and (d) harmonised conflict of law rules. Compared to the fragmented and uncertain state of affairs of some ten years ago, an enormous step forward has been made in providing a recognisable framework for cross-border insolvency, especially with regard to international jurisdiction, recognition of judgments, choice of law provisions, position of creditors and powers of office holders. Cross-border insolvencies in the EU have become much more predictable and a step in the right direction has been made by the moderate choice for a model of coordinated universality. The significance and influence of the regulation in terms of the search for solutions to problems arising in cross-border insolvencies cannot be overestimated. Insolvency specialists and advisers in the field of financial relationships will have to be more than aware of the regulation's existence and the way in which courts in several jurisdictions have interpreted its provisions. Provisional conclusion therefore: the balance appears to be positive.

On the other hand the handling of cross-border insolvencies within the Community could certainly be improved. Last year a list of 20 recommendations was published, which is by no means exhaustive. ${ }^{40}$ For a list of suggestions for

40 Wessels 2006 International Caselaw Alert 68ff; also available at Wessels http://www.bobwessels.nl 18 Feb (Blog 2006-09-doc4). 
improvements, see too the comments of Moss and Paulus ${ }^{41}$ and of Omar. ${ }^{42}$

Recommendations in this contribution are presented with the intention of providing food for thought for the evaluation process pursuant to article 46 InsReg. Article 46 provides that no later than 1 June 2012, and every five years thereafter, the commission shall present to the European Parliament, the Council and the Economic and Social Committee a report on the application of the regulation, which shall be accompanied if need be by a proposal for adaptation of the regulation. Observations in this contribution relate among others to the inflexible nature of a regulation as a community measure itself, the lack of a European wide system of registration of openings of insolvency proceedings and related decisions, the uncertainties the conflict of law rules present ${ }^{43}$ and the unsatisfactory procedural framework of the regulation. This may be explained by the connection between the origins of the regulation and what is (now) the Brussels Regulation 2002. The Insolvency Regulation aimed to close a gap in the system of international jurisdiction and recognition of judgments relating to civil, commercial and insolvency matters, but courts in Germany and the Netherlands nevertheless have given rulings which are based on the assessment that both regulations were not applicable. ${ }^{44}$ Also alignment with other areas of EU law, particularly EU corporate law is lacking, for example, alignment with the (future) EC directives relating to transfers of corporate seats and cross-border mergers and the characterisation of certain

41 Moss and Paulus 2005 Insolvency Intelligence.

42 Omar 2007 Insolvency Intelligence; see also Omar 2006 International Case-Law Alert http://www.eir-database.com 19 Feb.

43 See Wessels http://www.bobwessels.nl 18 Feb (Blog 2007-06-doc2).

44 See for instance District Court Frankfurt am Main 26 January 2006, ZIP 2006, 796 and District Court of Rotterdam 7 June 2006, JOR 2006/52. The Frankfurt decision has been referred to the European Court of Justice by the German Supreme Court, with its judgment of 21 July 2007. 
rules as falling under the domain of insolvency law or corporate law. ${ }^{45}$ In addition, the regulation's compatibility with domestic legal systems of Member States leave much to the activity of Member States, where some guidance from the regulation would have been welcome, for example, articles 31-37 and the lack of any procedural rules. ${ }^{46}$ Another group of recommendations relate to the topic of international jurisdiction. As signalled above in dozens of court cases the general description for 'centre of main interest' is not sufficient to encompass all types of debtors, for example, natural persons as private persons, natural persons as professionals, smaller companies and larger (groups of) companies with segregated 'management and control' ('head office functions') and factual operations. ${ }^{47}$ In addition, the 'COMl' decision seems to be too 'compressed' as a court's decision on the opening of insolvency proceedings also comprises - by matter of law - the decision concerning the applicable law, the extension of this law and of the powers of the liquidator throughout Europe. ${ }^{48}$ There is no guarantee that the information the court receives is complete, an uncontested decision can be made by a party who has an interest. Several procedural rules lack or seem vague, for example, the procedural rights and duties of parties - including creditors - to be involved in the 'COMl' decision, including the full and fair opportunity to present the facts and the law of a parties' case and, likewise, the same opportunity to comment on evidence and legal arguments provided by other parties. ${ }^{49}$

45 See Wessels 2005 European Company Law 50ff and Omar 2005 European Company Law $59 \mathrm{ff}$.

46 When this article is published, INSOL Europe (an insolvency practitioners' organisation) will publish its European Communication and Cooperation Guidelines for Cross-border Insolvency, drafted by Miguel Virgós and me, which aim to enable liquidators and courts to operate efficiently and effectively in cross-border insolvency proceedings.

47 The decision of the European Court of Justice 2 May 2006 only provides a first step in clarifying the interpretation of COMI, see Wessels 2006 European Company Law 183ff.

48 See Bufford 2006 Columbia Journal of European Law 429.

49 See Bufford 2007 Northwestern Journal of International Law and Business 351. 


\section{Building beyond the Insolvency Regulation}

At least three other topics deserve to be mentioned in the category of what is not offered under the Insolvency Regulation. As recital 11 indirectly indicates, the Insolvency Regulation is based on the idea, generally accepted over the last few decades, that harmonisation of domestic rules relating to insolvency was impossible given the differences in substantive laws, including preferential rights. See the earlier publication ${ }^{50}$ with reference to, for example, differences in the way in which businesses are financed, protection policies of certain interest groups and different cultures in relation to the social phenomenon of 'insolvency'. It should nevertheless be mentioned that several provisions of the regulation are characterised as substantive rules and are therefore now accepted throughout Europe as unified rules concerning the topics to which they relate, see for example articles 7(2), 20, 29-35, 39 and 40. A next step to be taken is an assessment of the topics (procedural; substantial) which may be ready for (degrees of) harmonisation. ${ }^{51}$

Secondly, it is a popular criticism that the regulation lacks provisions concerning groups of companies. It is always with reluctance to criticise the regulation for its lack of provisions relating to the insolvency of one or more companies, which, along with other companies, form a group of corporations. A personal opinion is that critics have paid too little attention to the history of the regulation and its basis in the EC-Treaty as a measure concerning 'procedural law', necessary for the creation of one European 'area of freedom, security and justice', which calls for measures relating to judicial cooperation in civil matters needed for the proper functioning of the internal market. This area falls within

50 Wessels Insolvency Law 294-311.

51 See Wessels Tijdschrift voor Belgisch Handelsrecht (forthcoming).

93/211 
the scope of article 65 of the EC-Treaty. The Insolvency regulation is not related to the development of a system of 'corporate law' or the idea of free establishment as meant in article 42ff of the EC-Treaty. Nevertheless, several court cases demonstrate the need for the regulation to provide a solid set of rules, not just those related to 'international jurisdiction' of a court. Changes could also be considered with regard to the nature of secondary proceedings, to the powers of the main liquidator, the establishment of a committee of creditors which duly represents the involved corporate debtors (parent company and subsidiaries) or certain forms of consolidation and the treatment of inter-company loans.

And finally, Europe's relation with regard to cross-border insolvency to South Africa.

To a great extent the regulation only applies within the territory of the community (except for Denmark). The consequences for debtors or creditors outside of the community are limited. ${ }^{52}$ The reason for the limitation can be understood in a historical and political context, but is clearly at odds with growing patterns of globalising business and financial relationships. Commonly, in trading or financial relationships with for example, Denmark, Norway, Switzerland, Turkey or the USA and South Africa the COMI is located outside the community, thus, a debtor will remain untouched by the Insolvency Regulation. The scope of the regulation could be extended to other countries such as Denmark, Norway, Switzerland and Iceland, in a similar manner to that used for the (now) Brussels Regulation 2002 and the connected Treaty of Lugano. In earlier publications ${ }^{53}$ the opportunity has been expressed for the EU

52 Marquette and Barbé Insolvency Proceedings 419ff.

53 See Wessels International Insolvency Law (2003 ed) and Wessels International Insolvency par $10967 \mathrm{ff}$. 
to closely adopt the UNCITRAL Model Law ${ }^{54}$ on an EC level. Compared to some five years ago, though, the option of collective enactment of (large parts of) the Model Law seems far away or at least less realistic, as several European countries have introduced their own approaches of either enacting their versions of the Model Law (Poland, Romania and UK) or their own versions of international insolvency law provisions (for example, Germany, Belgium and Spain) during the last few years. Here it should be noted though that for instance Germany and Spain have extended the conflict of law rules for a large part to other (non EU member) states. In the Netherlands this is seen as a welcome element for a solid system of international insolvency law, which is presently - with its Bankruptcy Act of 1896 - lacking.

This will be reflected in a draft for new legislation, which may be expected in the near future.

\section{Conclusion}

The developments which have taken place in the last five years in the area of international insolvency in Europe have been turbulent. There is no time to sit back and relax though. The system of the EU Insolvency Regulation which is in place works, but it could work much better. Some of the suggestions made above may assist in reaching for an even stronger framework for the operation of the regulation and therefore solving more efficiently and effectively crossborder insolvency cases. 


\section{Bibliography}

Bufford 2006 Columbia Journal of European Law 429

Bufford SL "International Insolvency Case Venue in the European Union: The Parmalat and Daisytek Controversies" 2006 (12) Columbia Journal of European Law 429

Bufford 2007 Northwestern Journal of International Law and Business 351 Bufford SL "Center of Main Interests, International Insolvency Case Venue and Equality of Arms: The Eurofood Decision of the European Court of Justice" 2007 Northwestern Journal of International Law and Business 351

Collins et al (eds) Conflict of Laws Collins L et al (eds) Dicey, Morris and Collins on The Conflict of Laws $14^{\text {th }}$ rev ed (Sweet \& Maxwell London 2007)

Huber Europäischen Insolvenzverordnung 397 Huber U "Inländische Insolvenzverfahren über Auslandgesellschaften nach der Europäischen Insolvenzverordnung" in Schilken E et al (eds) Festschrift für Walter Gerhardt (RWS Verlag Kommunikationsforum Köln 2004)

Janger 2007 Brooklyn Journal of International Law (forthcoming) Janger EJ "Universal Proceduralism" Paper presented at the symposium Bankruptcy in The Global Village - The Second Decade (Brooklyn School of Law 20-21 October 2006) 2007 (32) Brooklyn Journal of International Law (forthcoming)

Kolmann Kooperationsmodelle

Kolmann S Kooperationsmodelle im Internationalen Insolvenzrecht. Empfielt sich für das Deutsche internationale Insolvenzrecht eine Neuorientierung? Schriften zum Deutschen und Europäischen Zivil-, 
Handels- und Prozessrecht (Verlag Ernst und Werner Gieseking Bielefeld 2001)

Marquette and Barbé Insolvency Proceedings 419

Marquette V and Barbé C "Council Regulation (EC) No 1346/2000 Insolvency Proceedings in Europe and Third Countries: Status and Prospects" in Nuyts A and Watté N (eds) International Civil Litigation in Europe and Relations with Third States (Bruxelles Bruylant 2005)

Moss and Paulus 2005 Insolvency Intelligence

Moss G and Paulus C "The European Insolvency Regulation - The Case for Urgent Reform" 2005 Insolvency Intelligence October

Moss and Wessels (eds) EU Banking and Insurance Insolvency Moss G and Wessels B (eds) EU Banking and Insurance Insolvency: An Annotated Guide and Comments on the Implementation of EC Directives 17/2001 and 24/2001 in EU Member States (Oxford University Press Oxford 2006)

Omar 2005 European Company Law 59

Omar PJ "The Convergence of Company and Insolvency Initiatives within the European Union" 2005 (2) European Company Law 59

Omar 2007 Insolvency Intelligence

Omar PJ "Addressing the Reform of the European Insolvency Regulation: Wishlist or Fancies?" 2007 Insolvency Intelligence January

Virgós 1998 Forum Internationale 11

Virgós M "The 1995 European Community Convention on Insolvency Proceedings: An Insider's View" 1998 (25) Forum Internationale 11 
Wessels Insolvency Law 294-311

Wessels B "Insolvency Law" in Smits J (ed) Encyclopaedia of Comparative Law (Edgar Elgar London 2006) 294-311

Wessels 2005 European Company Law 50

Wessels B "The EC Insolvency Regulation: Three Years in Force" 2005 (2) European Company Law 50

Wessels 2005 International Corporate Rescue 291

Wessels B "It's Time to Cooperate" Editorial 2005 (2) International Corporate Rescue 291

Wessels 2006 European Company Law 183

Wessels B "The Place of the Registered Office of a Company: A

Cornerstone in the Application of the EC Insolvency Regulation" 2006 (3) European Company Law 183

Wessels 2006 International Caselaw Alert 68

Wessels B "Twenty Suggestions for a makeover of the EU Insolvency

Regulation" 2006 (12) International Caselaw Alert 31 October

Wessels International Insolvency Law

Wessels B International Insolvency Law (Kluwer Deventer 2006)

Wessels International Insolvency Law (2003 ed)

Wessels B International Insolvency Law (Kluwer Deventer 2003)

Wessels Multinational Bank Insolvency 259

Wessels B "A Glance through the Legal Principles and Key Issues of Multinational Bank Insolvency" Paper presented at Insol International Academics meeting on The Treatment of Corporate Groups in Insolvency 
(Cape Town South Africa 2- 4 April 2004) in Current Topics of International Insolvency Law (Kluwer Deventer 2004)

Wessels Open Insolvency Proceedings 155

Wessels B "International Jurisdiction To Open Insolvency Proceedings In Europe, In Particular Against (Groups Of) Companies" in Current Topic of International Insolvency Law (Kluwer Deventer 2004)

Wessels Realisation 229

Wessels B "Realisation of the EU Insolvency Regulation in Germany, France and the Netherlands" in Current Topics of International Insolvency Law (Kluwer Deventer 2004)

Wessels Tijdschrift voor Belgisch Handelsrecht (forthcoming)

Wessels B "Europe Deserves a New Approach to Insolvency Proceedings" Contribution to the Colloquium Two hundred years Commercial Code of Belgium (Brussels Belgium 23 March 2007) Tijdschrift voor Belgisch Handelsrecht (forthcoming)

Westbrook 2004 Texas Law Review 795

Westbrook JL "The Control of Wealth in Bankruptcy" 2004 (82) Texas Law Review 795

\section{Register of legislation}

Amministrazione straordaninaria delle grandi impresi in stato di insolvenza No 347 of 23 December 2003

Regulation (EC) No 1346/2000 of 29 May 2000

GURI No 298 of 24 December 2003

\section{Register of court cases}

BRAC Rent-A-Car International Inc [2003] 1 WLR 401421 
Court of Appeal Skåne and Blekinge No Ö 21-05 3 February 2005

Court of Stockholm K 17664-04 21 January 2005

District Court Dordrecht LJN: AU7353 23 November 2005

District Court Frankfurt am Main 26 January 2006, ZIP 2006, 796

District Court of Rotterdam 7 June 2006, JOR 2006/52

Eurofood ECJ C-341/04 2 May 2006

German Supreme Court ZIP 2006, 529 of 9 February 2006; NZI 2006, 297

JOR 2006/59

Netherlands Supreme Court JOR 2004/87 9 January 2004

Re Aim Underwriting Agencies (Ireland) Ltd Ch D 2 July 2004

Re Cedarlease Ltd 8 March 2005

Re Ci4net.com Inc

Re Collins \& Aikman Europe SA [2005] EWCH 1754 (Ch)

Re Daisytek-ISA Ltd [2004] BPIR 30

Re DBP Holdings Limited Ch D 20 May 2004

Re Eurofood IFSC Limited

Re Hettlage KgaA 4 May 2004

Re Sendo Ltd [2005] EWHC 1604 (Ch)

Susanne Staubitz-Schreiber ECJ C-01/04 17 January 2006

Svea Court of Appeal No Ö 4105-03 30 May 2003

\section{Register of treaties and conventions}

Brussels Convention on Jurisdiction and the Enforcement of Judgments in Civil and Commercial Matters 1968

Brussels Regulation 2000

Brussels Regulation 2002

Council Regulation 44/2001 22 December 2000

OJL 1222 December 2001

Treaty of Lugano 1993

\section{Register of Internet resources}


Omar 2006 International Case-Law Alert http://www.eir-database.com 19 Feb Omar PJ "Confronting the Challenge of Diverse Priority Rules through the European Insolvency Regulation" 2006 (10) International Case-Law Alert June [Found on internet] http://www.eir-database.com [Date of use 19 February 2008]

Pottow 2005 Virg J Int'/ L http://ssrn.com/abstract=646962 27 Feb Pottow J "Procedural Incrementalism: A Model for International Bankruptcy" 200545 (4) Virginia Journal of International Law [Found on internet] http://ssrn.com/abstract=646962 [Date of use 27February 2008]

Rasmussen 2007 Vanderbilt Law and Economics http://ssrn.com/ 18 Feb Rasmussen RK "Where Are All the Transnational Bankruptcies?: The Puzzling Case for Universalism" Working Paper No 07-13 2007 Vanderbilt Law and Economics [Found on internet] http://ssrn.com/abstract=982678 [Date of use 18 February 2008]

UNCITRAL Model Law http://www.uncitral.org/ 19 Feb

UNCITRAL Model Law on Cross-Border Insolvency 1997 [Found on internet]

http://www.uncitral.org/uncitral/en/uncitral texts/insolvency/1997Model.html [Date of use 19 Feb 2008]

Wessels http://www.bobwessels.nl 18 Feb (Blog 2006-09-doc4)

Wessels B "Twenty Suggestions for a makeover of the EU Insolvency

Regulation" Blog 2006-09-doc4 [Found on internet] http://www.bobwessels.nl [Date of use 18 February 2008]

Wessels http://www.bobwessels.nl 18 Feb (Blog 2007-01-doc16)

Wessels B "The Insolvency Regulation - consolidated version" Blog 2007- 
01-doc16 [Found on internet] http://www.bobwessels.nl [Date of use 18 February 2008]

Wessels http://www.bobwessels.nl 18 Feb (Blog 2007-06-doc2)

Wessels B "Applicable Law in Cross-border Insolvency Proceedings" Joint conference of the American Law Institute and the International Insolvency Institute on Principles for Cooperation in International Insolvency Cases (Columbia University School of Law New York City 13 June 2007) Blog 2007-06-doc2 [Found on internet] http://www.bobwessels.nl 19 Feb

Wessels http://www.bobwessels.nl 18 Feb (Blog 2007-06-doc3)

Wessels B "The Insolvency Regulation - amended annexes" Blog 2007-06doc3 [Found on internet] http://www.bobwessels.nl [Date of use 18 February 2008]

\section{List of abbreviations}

$\begin{array}{ll}\text { art } & \text { article(s) } \\ \text { ch } & \text { chapter(s) } \\ \text { COMI } & \text { centre of main interest(s) } \\ \text { ECJ } & \text { European Court of Justice } \\ \text { EEA } & \text { European Economic Area } \\ \text { InsReg } & \text { EU Insolvency Regulation } \\ \text { par } & \text { paragraph(s) } \\ \text { reg } & \text { regulation(s) } \\ \mathrm{s} & \text { section(s) }\end{array}$

